\title{
A Preliminary Study of Thermal Comfort in Malaysia's Single Storey Terraced Houses
}

\author{
Agung Murti Nugroho*1, Mohd Hamdan Ahmad ${ }^{2}$ and Dilshan Remaz Ossen ${ }^{3}$ \\ ${ }^{1}$ Lecturer, Faculty of Engineering, Brawijaya University, Malang, Indonesia; Ph.D. Candidate, Faculty of Built Environment, \\ Universiti Teknologi Malaysia, Johor DT, Malaysia \\ ${ }^{2}$ Associate Professor, Faculty of Built Environment, Universiti Teknologi Malaysia, Johor DT, Malaysia \\ ${ }^{3}$ Lecturer, Faculty of Built Environment, Universiti Teknologi Malaysia, Johor DT, Malaysia
}

\begin{abstract}
In a tropical climate, passive cooling is difficult to achieve with respect to mass housing design. A good house design keeps the indoor environment favorable and comfortable during most of the year without the use of any mechanical devices. Terraced houses are typical examples with low comfort problem that need particular consideration. Low air velocity and high air temperature are experienced during the daytime and the wind effect is not well captured, especially in the single sided ventilation. Use of natural ventilation has been increasingly examined as an energy-efficient means to provide thermal comfort as well as a healthy indoor environment. This paper discusses the validation of Computational Fluid Dynamic (CFD) results and the measurement of thermal comfort in Malaysia's single storey terraced houses. The thermal environment and comfort conditions were investigated using field measurement and CFD technique. Validation of CFD FloVent was carried out through the comparison of field measurements. Comparison of the results between simulations and measurements illustrated a good agreement. The simulations were performed on a selected day in a one-year climate condition. The results indicated that the design of single storey terraced houses is not effective in providing natural ventilation for achieving thermal comfort. The microclimate condition surrounding the terraced house indicated very low wind speed. Therefore, modification of the natural ventilation mechanism using a solar chimney as induced ventilation needs to be manifested and evaluated.
\end{abstract}

Keywords: thermal environment; thermal comfort; terraced house; natural ventilation

\section{Introduction}

The tropical humid climate, especially in Malaysia is mainly characterized by elevated temperatures and high relative air humidity. Dehumidification is one way of solving the problem of high humidity percentages with sufficient airflow through the buildings thus restoring comfort. Therefore, provision for air movement must be one of the most important considerations in building design. Prianto and Depecker (2001) stated, as found by Fanger and Toftum, the air temperature and humidity combined in the enthalpy have a strong impact on perceived air quality, and perceived air quality determines the required ventilation in ventilation standard.

Thermal comfort can be defined as a condition of the mind, which expresses satisfaction with thermal environment (Fanger, 1972). In another experiment, De Wall (1993) suggests air movement inside buildings need to be set between $0.1 \mathrm{~m} / \mathrm{s}$ and $1.5 \mathrm{~m} / \mathrm{s}$ to provide indoor thermal comfort. A recent study by Griefahn

*Contact Author: Agung Murti Nugroho, Lecturer, Faculty of Engineering, Brawijaya University, Malang, Indonesia Fax: +62-341-551-430

E-mail: sasimurti@yahoo.co.id

(Received October 5, 2006 ; accepted March 13, 2007) et al. emphasizes that persons were less sensitive to draught when working at an increased activity level than when working at lower activity level (Griefahn, et al. 2000).

The environmental parameters to determine thermal comfort are air temperature (Ta), mean radiant temperature $(\mathrm{MRT})$, water vapour pressure $(\mathrm{Pa})$ or relative humidity $(\mathrm{RH})$, relative air velocity $(\mathrm{Vt})$, and personal parameters: clothing or thermal resistance and activity or metabolic rate (M) (Fanger, 1972). However, it is reasonable to consider that all design variables are interdependent. This paper is aimed at investigating indoor thermal environment and comfort condition of a terraced house in Malaysia, based on field measurement and simulation. Air temperature and the relative humidity were selected as the main variables to determine the thermal environment. The field measurements were obtained by using the Compact Humidity Logger (CHL), and Thermal Data Logger (TDG). The simulations were performed by Computational Fluid Dynamic (CFD) to account for indoor thermal environment (TE) and thermal comfort (TC).

\subsection{Malaysia's Climate Condition}

Malaysia's climate is characterized by high relative humidity and air temperature. Malaysia lies between 
$1^{\circ}$ and $7^{\circ}$ North latitude and $100^{\circ}$ and $120^{\circ}$ East longitudes. It has two land areas; Peninsular Malaysia and East Malaysia. The present study is conducted in Peninsular as it consists $76 \%$ of the population. Most towns in the Peninsular experience a seasonal climatic change dominated by the monsoons. Johor Bahru is the second largest town after Kuala Lumpur and located at the southernmost part of Peninsular. The seasonal pattern of wind and rainfall is a dominant climatic characteristic in this region. Monsoon winds occur twice a year, i.e. the Northeast and Southwest monsoon. The Southwest monsoon originates from Australia and blows over Sumatra Island and the Straits of Malacca during the months of May to September. The Northeast monsoon originates from the central Asian continent and blows across the South China Sea through Malaysia to Australia during the months of November to March. During the months of April and October, inter-monsoon winds occur.

According to the meteorological data for the year 2005 in Senai, Johor Bahru, the mean monthly air temperature remains constant. This varies by only $2^{\circ} \mathrm{C}$, from $25^{\circ} \mathrm{C}$ in January to $27^{\circ} \mathrm{C}$ in April. The average daily air temperature is about $26.5^{\circ} \mathrm{C}$ throughout the year. Relative humidity varies from 75 to 85 percent.

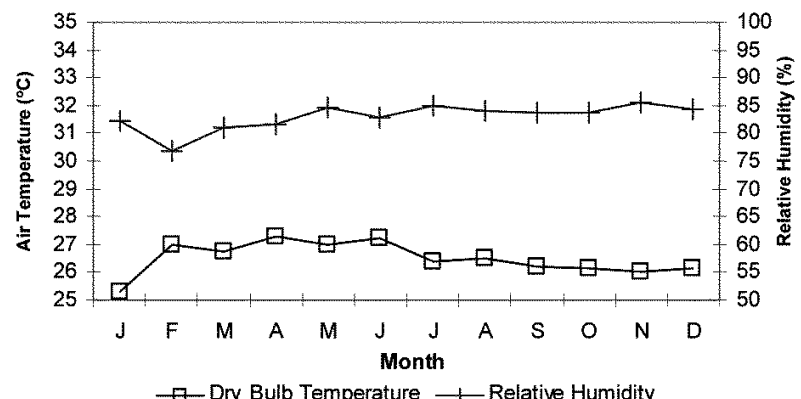

Fig.1. Seasonal pattern of dry bulb temperature and relative humidity (Data obtained $17.4 \mathrm{~m}$ above sea level at the Senai Meteorological Station, 2005)

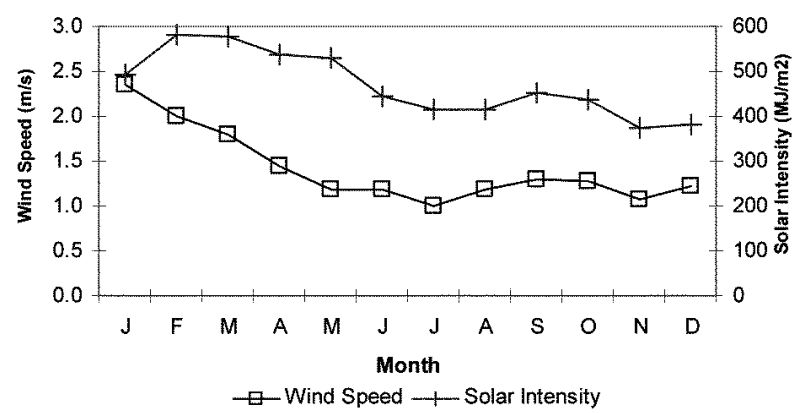

Fig.2. Seasonal pattern of solar intensity and wind speed (Data obtained $17.4 \mathrm{~m}$ above sea level at Senai Meteorological Station, 2005)

The intensity of solar radiation is $400 \mathrm{MJ} / \mathrm{m}^{2}$ to 600 $\mathrm{MJ} / \mathrm{m}^{2}$ each month, and is of high intensity during the Northeast monsoon and of low intensity during the Southwest monsoon periods. Fig. 1 and Fig. 2 show a combination of high global radiation with decreasing wind speed from February to June, which results in extremely over-heated period. During this period the mean air temperatures also indicated higher values.

\subsection{Terraced Houses in Malaysia}

The property market report indicated that terraced houses accounted for approximately $57 \%$ of the total Malaysian housing stock in the year 2002 (Kubota, et al. 2006). The majority of terraced houses are concentrated in Johor Bahru. Further, more than $50 \%$ of them are single storey. In order to assess the thermal environment and thermal comfort conditions, a preliminary investigation was conducted in March 2006 (Nugroho, et al. 2006). Therefore a typical single storey terraced house was used for the investigation in Johor Bahru, Malaysia (Fig.3). The terraced house layouts are parallel to the road which is $10 \mathrm{~m}$ width and in a suburban area. The particular house used in the study is in between two terraced houses of a typical row. The typical size of the lot is about $7 \mathrm{~m}$ in width and $20 \mathrm{~m}$ in depth.

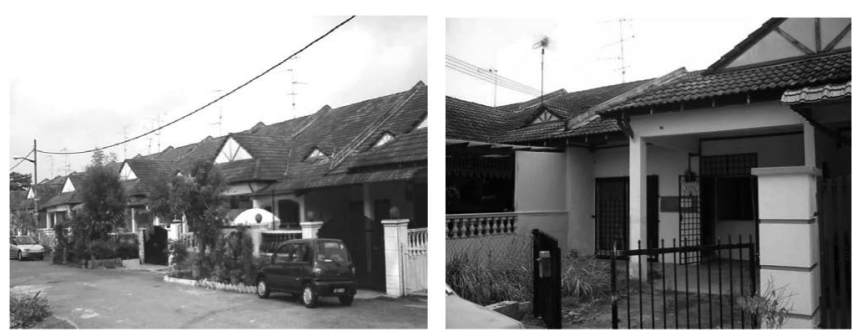

Fig.3. A single storey terraced house in Johor Bahru, used for field measurements

\section{Methods}

\subsection{Field Measurement}

The authors carried out a survey to determine the environmental parameters of a typical single storey terraced house in Taman Sri Pulai housing estate, Johor Bahru on two consecutive dates from March 20th to 21st, 2006. The house comprised five rooms and was kept empty without furniture to reduce the thermal exchange between objects. The windows of the living and master bedroom are facing towards the east. The windows of the kitchen and two bedrooms face toward the west. Except for the living room, all other rooms received ventilation with single side openings. The windows have double sashes, which were retrofitted by the occupants. The window sashes ( $1 \mathrm{~m}$ height, $1.5 \mathrm{~m}$ width, and $1 \mathrm{~m}$ above the floor) are fixed in the kitchen and bedrooms while the living room had a sliding window ( $2 \mathrm{~m}$ height, $1 \mathrm{~m}$ width, $0.2 \mathrm{~m}$ above the floor). In a typical Malaysian dwelling, the windows are usually kept open during the day and closed at night in both present and traditional practice (for security). During the measurement, all doors remained closed and all windows of the house remained open. The walls and roofs are not insulated for heat transmission. The building structure consists of $150 \mathrm{~mm}$ thick brick walls (including cement and lime plaster). The thickness of the outside and inside walls is $20 \mathrm{~cm}$ and $15 \mathrm{~cm}$ respectively. The total $U$ value for the walls was about 


\section{$0.5 \mathrm{~W} / \mathrm{m}^{2} \mathrm{~K}$.}

The instrumentation consisted of sensors with a data logger system. The sensors were setup to monitor outdoor and indoor climatic conditions. Fig.4. shows the positions of the instrument installation within and outside the investigated house.

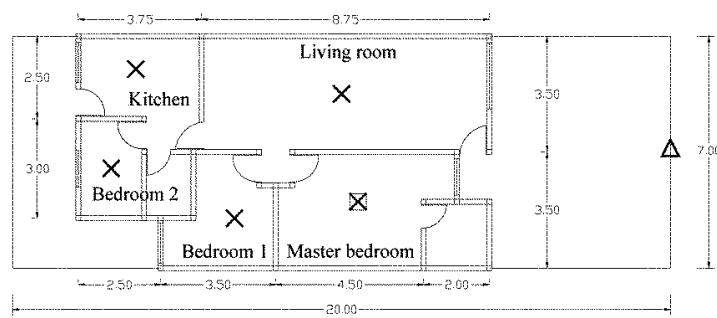

Fig.4. The positions of global weather data $(\Delta)$, compact data logger $(\times)$ and thermal data logger $(\square)$

Outdoor climatic conditions were collected using a globe weather station. The immediate surrounding environmental conditions were measured at $2 \mathrm{~m}$ above the ground. Data for solar radiation, wind speed, wind direction, air temperature and relative humidity were obtained using the globe weather station. Indoor climatic conditions were collected with a thermal data logger and compact data loggers. The Inova thermal data logger obtained data on environmental parameters (air temperature, mean radiant temperature, relative humidity and wind speed), which were necessary for further thermal comfort analysis. The Dickson compact humidity loggers measured air temperature and relative humidity, which were carefully calibrated with the thermal data logger beforehand to give reliable results.

The metabolic heat productions were assumed as light activity, while seated (1 met) and the clothing insulation was taken from De Wall (1993) appropriate to tropical humid regions. The clothing insulation value 0.55 clo was adopted, which is a suitable value for tropical clothing. In this study, the thermal environment and thermal comfort were measured at $1.10 \mathrm{~m}$ (human body level) above the floor where indoor air temperatures and relative humidity were observed in the four rooms (living room, bedroom 1 , bedroom 2 and kitchen) and complete thermal comfort measurement in the master bedroom of the single storey building. The time step is 15 minutes for all automatic measurement. Hence, the thermal environment and the thermal comfort were investigated during $00.00 \mathrm{~h}$ to $23.00 \mathrm{~h}$. Table 1 shows the details of subject rooms, data type, equipment used, data interval and height of measurement points.

\subsection{CFD Simulation}

The initial conditions for simulation have been set using the climatic data from the field measurement obtained between $08.00 \mathrm{~h}$ to $19.00 \mathrm{~h}$ on 21 March 2006 (Table 2). All tests on five rooms were carried out by using the CFD FloVent simulation program. Fig.5 shows the CFD model and boundary conditions. The CFD program requires inputs representing the problem
Table 1. The measurement items and method

\begin{tabular}{|c|c|c|c|c|}
\hline Room & Data Type & Equipment & Interval & Height \\
\hline $\begin{array}{l}\text { Living } \\
\text { Room }\end{array}$ & $\begin{array}{l}\text { Air temp. } \\
\text { Humidity }\end{array}$ & $\begin{array}{l}\text { Dickson } \\
\text { CHL }\end{array}$ & $\begin{array}{c}15 \\
\text { minutes }\end{array}$ & $\begin{array}{l}1.1 \mathrm{~m} \text { above } \\
\text { the floor }\end{array}$ \\
\hline $\begin{array}{c}\text { Bedroom } \\
1\end{array}$ & $\begin{array}{l}\text { Air temp. } \\
\text { Humidity }\end{array}$ & $\begin{array}{l}\text { Dickson } \\
\text { CHL }\end{array}$ & $\begin{array}{c}15 \\
\text { minutes }\end{array}$ & $\begin{array}{l}1.1 \mathrm{~m} \text { above } \\
\text { the floor }\end{array}$ \\
\hline $\begin{array}{c}\text { Bedroom } \\
2\end{array}$ & $\begin{array}{l}\text { Air temp. } \\
\text { Humidity }\end{array}$ & $\begin{array}{l}\text { Dickson } \\
\text { CHL }\end{array}$ & $\begin{array}{c}15 \\
\text { minutes }\end{array}$ & $\begin{array}{l}1.1 \mathrm{~m} \text { above } \\
\text { the floor }\end{array}$ \\
\hline Kitchen & $\begin{array}{l}\text { Air temp. } \\
\text { Humidity }\end{array}$ & $\begin{array}{l}\text { Dickson } \\
\text { CHL }\end{array}$ & $\begin{array}{c}15 \\
\text { minutes }\end{array}$ & $\begin{array}{c}1.1 \mathrm{~m} \text { above } \\
\text { the floor }\end{array}$ \\
\hline $\begin{array}{c}\text { Master } \\
\text { bedroom }\end{array}$ & $\begin{array}{l}\text { Air temp. } \\
\text { Humidity, } \\
\text { Mean radiant } \\
\text { temp., Air } \\
\text { velocity, } \\
\text { PMV }\end{array}$ & $\begin{array}{c}\text { Dickson } \\
\text { CHL } \\
\text { Inova TDL }\end{array}$ & $\begin{array}{c}15 \\
\text { minutes }\end{array}$ & $\begin{array}{l}1.1 \mathrm{~m} \text { above } \\
\text { the floor }\end{array}$ \\
\hline Outdoor & $\begin{array}{c}\text { Wind speed, } \\
\text { Air temp } \\
\text { Humidity } \\
\text { Solar } \\
\text { radiation } \\
\end{array}$ & $\begin{array}{c}\text { Globe } \\
\text { Weather } \\
\text { Station }\end{array}$ & $\begin{array}{c}15 \\
\text { minutes }\end{array}$ & $\begin{array}{c}2 \mathrm{~m} \text { above } \\
\text { the floor }\end{array}$ \\
\hline
\end{tabular}

type, flow domain (material, type of flow, etc.), boundary conditions (walls, inlet, outlet, symmetric wall), and calculation method. The problem type is used to activate calculation modules; in this case, flow, heat transfer, and turbulence modules. The flow domain was set as (air density: $1.149 \mathrm{~kg} / \mathrm{m}^{3}$, viscosity: $1.872 \mathrm{E}-005$, specific heat: $1007 \mathrm{~J} / \mathrm{kg}$. K, conductivity: $0.02643 \mathrm{~W} / \mathrm{m}$. K, temperature: $27.6^{\circ} \mathrm{C}-32.2^{\circ} \mathrm{C}$ ). The wind flow was set at a steady state, subjected to gravity of $9.8 \mathrm{~m} / \mathrm{s}^{2}$, and the flow regime was turbulent. Roughness height of the ground was set as 0.03 . Initial wind was defined at the inlet using an atmospheric boundary layer to obtain a realistic wind profile based on the exponent law (Ansley, et al. 1999). Based on site Global Weather data, the wind speed at $2 \mathrm{~m}$ above ground was $0-0.2 \mathrm{~m} / \mathrm{s}$. The turbulent kinetic energy and energy dissipation rate were set to 0.33 and 0.48 respectively. The calculation used the standard k-e epsilon turbulent model with 1500 iterations. To avoid convergence problems, fan relaxation 1 was applied. The solar radiation calculation was set to the following details (latitude: 1.8 degree, day: 21 March, solar times: 07.00h-18.00h, solar intensity: 4.09-118.57 $\mathrm{MJ} / \mathrm{m}^{2}$ ). The external walls (side) were considered as adiabatic, which means there is no heat transfer. The front, back walls and the floor $U$ values were $0.5 \mathrm{~W} / \mathrm{m}^{2} \mathrm{~K}(0.085 \mathrm{Btu} / \mathrm{Hr}-\mathrm{sq} \mathrm{ft}-\mathrm{F})$ respectively. The model was placed inside an overall domain solution size of $100 \mathrm{~m}$ length $\mathrm{x} 40 \mathrm{~m}$ height $\mathrm{x} 8 \mathrm{~m}$ width. The monitor point represents the air velocity and the air temperature tapping point was placed at the field measurement point. The simulation used the Cartesian type-grid system. The total number of cells produced from this grid system is 40 numbers (x-direction) $\mathrm{x} 22$ numbers (y-direction) x 10 numbers (z-direction). This produces 136,890 cells in total. Therefore, 136,890 control volumes carry out the numerical solution for this building. The distribution of air temperature, air velocity, mean radiant temperature and PMV have been analyzed. 
Table 2. Field Measurement Input Data for CFD simulation

\begin{tabular}{|c|c|c|c|c|c|}
\hline Time & $\begin{array}{c}\text { Air } \\
\text { temp. } \\
\left({ }^{\circ} \mathrm{C}\right)\end{array}$ & $\begin{array}{c}\text { Humidity } \\
(\%)\end{array}$ & $\begin{array}{c}\text { Wind } \\
\text { speed } \\
(\mathrm{m} / \mathrm{s})\end{array}$ & $\begin{array}{c}\text { Solar } \\
\text { radiation } \\
\left(\mathrm{MJ} / \mathrm{m}^{2}\right)\end{array}$ & $\begin{array}{c}\text { Wind } \\
\text { direction } \\
\left({ }^{\circ}\right)\end{array}$ \\
\hline 8 & 26.56 & 89.2 & 0 & 4.09 & 0 \\
\hline 9 & 28.89 & 79 & 0.03 & 16.65 & 0 \\
\hline 10 & 29.56 & 76.7 & 0 & 20.76 & 0 \\
\hline 11 & 27.50 & 78.6 & 0.1 & 80.00 & 178 \\
\hline 12 & 31.67 & 65.6 & 0.1 & 118.57 & 182 \\
\hline 13 & 29.67 & 72.8 & 0.3 & 71.37 & 180 \\
\hline 14 & 29.67 & 72.5 & 0.15 & 35.88 & 168 \\
\hline 15 & 28.11 & 78.6 & 0.1 & 15.55 & 176 \\
\hline 16 & 27.22 & 82.7 & 0.2 & 19.65 & 161 \\
\hline 17 & 27.22 & 82.5 & 0.05 & 44.24 & 178 \\
\hline 18 & 27.2 & 82.5 & 0.1 & 31.54 & 167 \\
\hline 19 & 26.8 & 89.2 & 0 & 6.23 & 0 \\
\hline
\end{tabular}

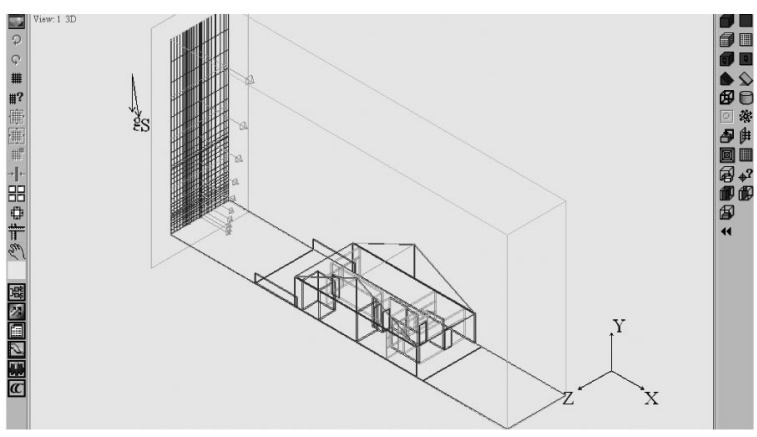

Fig.5. Terraced house model in CFD

\section{Results and Discussion}

3.1 Field Measurement: Outdoor Climate Condition

Daily climatic patterns in the tropics require climate conscious building design strategies to achieve thermal comfort. Outdoor air temperature and relative humidity for 21 March 2006 are plotted in Fig.6. According to Fig.6. the outdoor air temperature reached $31.6^{\circ} \mathrm{C}$ between 11:00h to $12: 00 \mathrm{~h}$ and during this period the relative humidity was at its minimum. The lowest air temperature was reported as $24.7^{\circ} \mathrm{C}$ at $23.00 \mathrm{~h}$ and the average air temperature was about $26.9^{\circ} \mathrm{C}$. The highest relative humidity was indicated as $97.4 \%$ at $06.00 \mathrm{~h}$ while the lowest relative humidity, which was $65.6 \%$, was reported at $12.00 \mathrm{~h}$. According to Nicol's comfort formula, the neutral air temperature needs to be maintained at $28.2^{\circ} \mathrm{C}$ (Humphreys, et al. 2001). However the data indicated that the daytime measured air temperature between $9.00 \mathrm{~h}$ and $15.00 \mathrm{~h}$ was above the required comfort level air temperatures except at $11.00 \mathrm{~h}$.

Solar intensity data on 21 March 2006 emphasized $118 \mathrm{MJ} / \mathrm{m}^{2}$ at 12:00 noon (Fig.7.). This value was measured as the highest on that particular date. Daily patterns of wind speed during the daytime are between 0.1 to $0.3 \mathrm{~m} / \mathrm{s}$ but comparatively higher than the very low wind speed $(0-0.05 \mathrm{~m} / \mathrm{s})$ at night and early morning. Thus, utilization of daytime ventilation with the use of cross ventilation strategy for improving the indoor thermal comfort has an insignificant impact. The wind speed is very low during the day and night

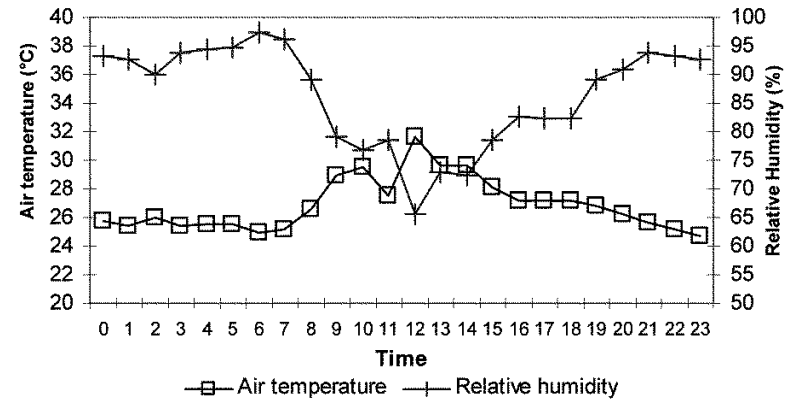

Fig.6. Diurnal pattern of air temperature and relative humidity (Data obtained $2 \mathrm{~m}$ above ground, on site at the Globe Weather Station, 21 March 2006)

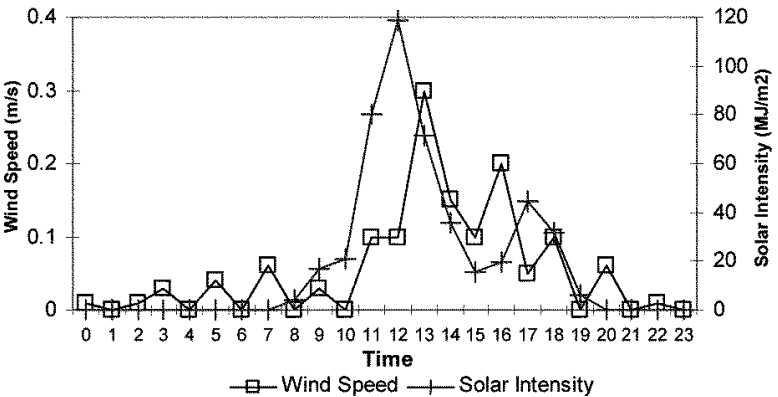

Fig.7. Diurnal pattern of solar radiation and wind speed (Data obtained $2 \mathrm{~m}$ above ground, on site at the Globe Weather Station, 21 March 2006)

time compared to accepted comfort. During the daytime the east-west wind direction is dominant with less diversity. However, such characteristics change during late evening and early morning with low air speed.

\subsection{Field Measurement: Indoor Thermal Environment}

Using the hourly data, the relationship between indoor and outdoor temperatures of a terraced house is shown in Fig.8. The change of indoor temperature is small compared with the outdoor temperature. It is clear that the indoor temperature of the terraced houses is higher than that of the outdoors except at $12.00 \mathrm{~h}$. Fig.8. indicates that the temperature in the master bedroom is higher in the morning hours and during noon hours compared to all the other rooms measured. Further, the daytime outside air temperature could be as high as $31.67^{\circ} \mathrm{C}$ because of the maximum solar radiation at $12: 00 \mathrm{~h}$.

During the morning and noon hours, the air temperature inside the building is almost the same as the outdoor air temperature. However, between $15.00 \mathrm{~h}$ and $19.00 \mathrm{~h}$ the inside air temperature is $2^{\circ}-3^{\circ}$ hotter than the outdoor air temperature. With the increase of solar radiation intensity, the indoor air temperature also increased and maintained a constant value of $30^{\circ} \mathrm{C}$ in the master bedroom. Further, bedroom 1 obtained an indoor air temperature of $30^{\circ} \mathrm{C}$ between $16: 00$ to $18: 00$ hours. This may be due to the fact that the room is oriented towards the west. 


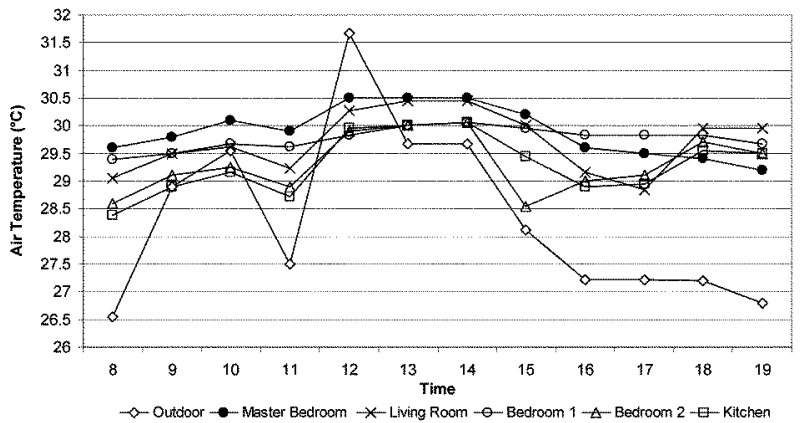

Fig.8. Temperature measurements result

(Data obtained $1.1 \mathrm{~m}$ above the floor, 21 March 2006)

The indoor thermal environment during the investigation demonstrated a similarity profile in the hourly pattern of temperature and relative humidity. Although differences in all rooms were observed, the extent of fluctuation was $0.5^{\circ}-1^{\circ} \mathrm{C}$ smaller than that on the outside $\left(0.5^{\circ}-4^{\circ} \mathrm{C}\right)$. The outside air temperature change was intense, while the inside air temperature remained stable compared to the outside. The inside air temperature was below $31^{\circ} \mathrm{C}$ when the outside maximum air temperature was about $32^{\circ} \mathrm{C}$. Further, as Nicol's comfort formula indicates, if the average indoor temperature is $29.5^{\circ} \mathrm{C}$ between $8.00 \mathrm{~h}$ and $19.00 \mathrm{~h}$, the particular room is above the comfort zone. However, the maximum and minimum average temperatures in the master bedroom and the kitchen are $29.9^{\circ} \mathrm{C}$ and $29.2^{\circ} \mathrm{C}$ respectively. Hence, the single day measurements (21 March 2006) indicated that the case study of a single storey terraced house is within the discomfort zone.

Fig.9. indicated that the outdoor relative humidity ratio is lower than the indoor relative humidity level during the daytime. After the inside air is heated at noon to the level of the outdoor air temperature, its relative humidity remains essentially the same for a few hours. The results emphasized the highest relative humidity in the kitchen and the lowest in the master bedroom. The lower limit of relative humidity is around $80 \%$. The range is slightly more for conditions with no or slow air movement and decreases with higher air speeds. The relative humidity inside the kitchen fluctuated from $85 \%$ to $95 \%$, and the master bedroom from $80 \%$ to $85 \%$. The relative humidity of the kitchen was a little higher than that of the master bedroom. Further, the air temperature of the master bedroom exceeds by about $0.5^{\circ}-1^{\circ} \mathrm{C}$ that of the temperature of the other room at noon. The reason may be explained by the fact that the master bedroom received solar heat in the morning, and since there is inadequate air velocity the solar heat accumulates.

\subsection{Indoor Thermal Comfort Analysis in the Master Bedroom}

In this study, PMV index by Fanger is used in the Inova Thermal Data Logger equipment and also part of the CFD calculation A complete description of the

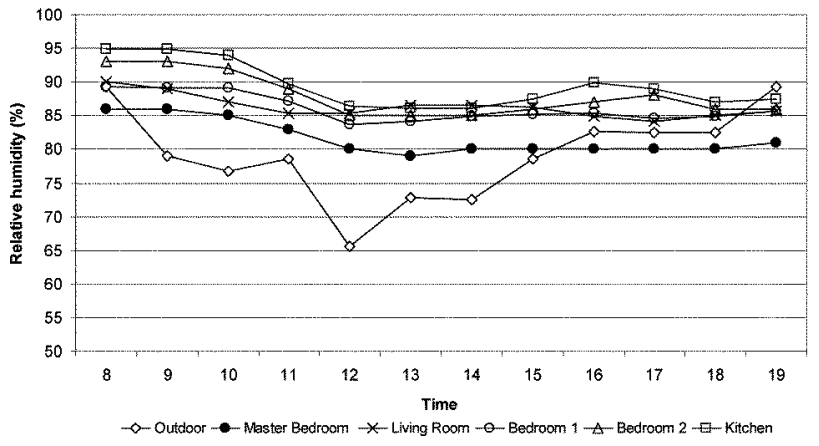

Fig.9. Humidity measurements result (Data obtained $1.1 \mathrm{~m}$ above the floor, 21 March 2006)

index PMV is described numerically as: cold (-3), cool $(-2)$, slightly cool $(-1)$, neutral $(0)$, slightly warm $(+1)$, warm $(+2)$ and hot $(+3)$. Inspection of the thermal comfort performance results in the master bedroom is presented in Fig.10. The air velocity measurements illustrate that air velocity induced flow has been established inside the room. The velocity flow inside the master bedroom could reach the values of $0-$ $0.001 \mathrm{~m} / \mathrm{s}$ and even more. The PMV distribution at the height of $1.1 \mathrm{~m}$ in the master bedroom illustrates that during the afternoon hours, the inside predicted mean vote (PMV) is noticeably lower $(+0.5)$ than at noon $(+2)$. The PMV was slightly warm (between +1 to +2 ) in the morning, and changed to warm at noon $(+2.0)$ when the outside temperature became high. In the afternoon the value was +0.5 , which showed as a near neutral thermal comfort condition.

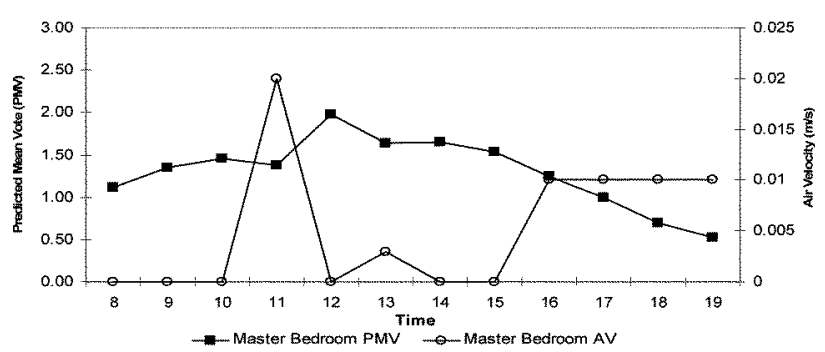

Fig.10. The PMV and air velocity measurements of the master bedroom (21 March 2006)

\subsection{Validation of CFD Simulation}

Validation of the CFD model with the field measurement results was carried out in two steps. The first step was the validation of air temperatures at consecutive times and the second step was the validation of the air velocity. The purpose of this twostep validation is to find the cause of deviation between the two results.

Fig. 11. emphasizes a good agreement between CFD simulations with the field measurement results, which indicates no difference with the outdoor air temperature. The difference is less than $10 \%$ for most of the calculated points on the air temperature in the master bedroom (Fig.12.). The average differences were less than $0.03^{\circ} \mathrm{C}$ and $1.69^{\circ} \mathrm{C}$ in the outdoor and 
indoor results between CFD and actual measurement of the master bedroom. In conclusion, the outdoor or ambient and indoor air temperature calculated by the CFD simulation showed a good agreement with the results of the field measurement.

Fig.13. illustrates the field measurement and CFD simulation for air velocity under outdoor and indoor conditions. The figure shows close agreement between the measured and simulation values. Deviations are within a range of $10 \%$ of the calculated air velocity. In most observations, this difference is less than $5 \%$ of the calculated values.

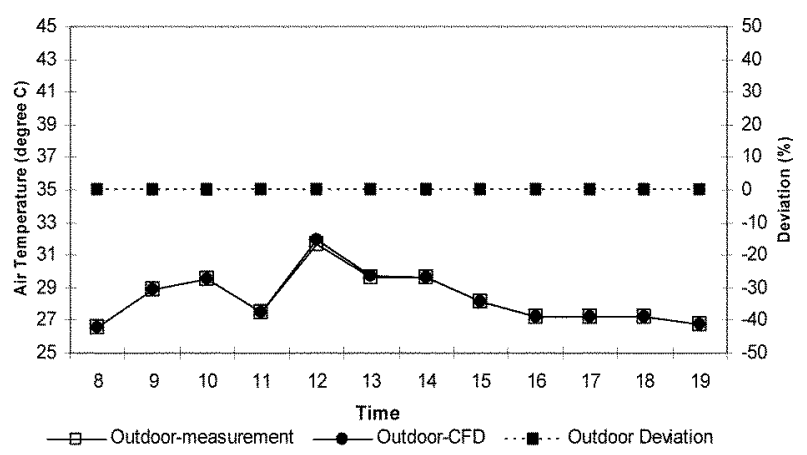

Fig.11. Comparison of the outdoor temperature result between field measurement and simulation (21 March 2006)

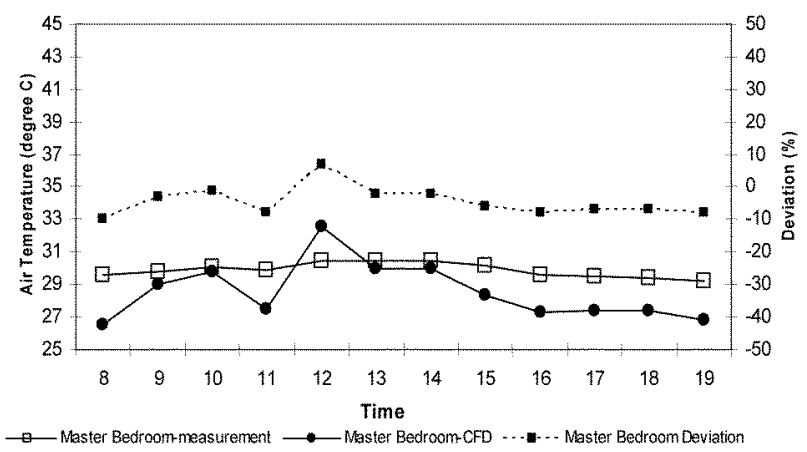

Fig.12. Comparison of the indoor temperature result between field measurement and simulation (21 March 2006)

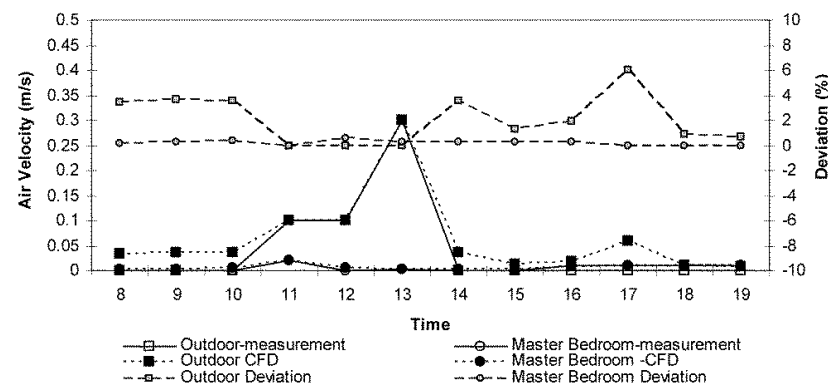

Fig.13. Comparison of the air flow velocity result between field measurement and simulation (21 March 2006)

Although there are slight differences between the results of CFD and field measurement, it can be inferred that the CFD modeling is appropriate to reproduce the phenomena occurring in the measurements. The use of the CFD model to investigate the performance of the thermal comfort ventilation thereby is validated.

\subsection{CFD Simulation Result of Indoor Thermal Comfort in a Single Storey Terraced House}

The PMV values are evaluated using CFD simulation in each room of the selected single storey terraced house. The simulation was performed between 08.00h to 19.00h (21 March 2006). Comparison of PMV results between measured and CFD simulations were shown in Fig.14. Comparison of simulated and measured PMV showed that the CFD thermal model indicated lower value especially in the afternoon hours.

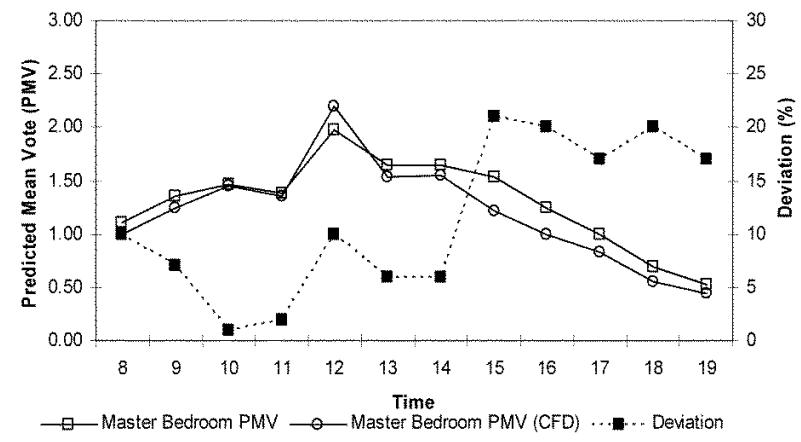

Fig.14. Comparison of the PMV result between field measurement and simulation (21 March 2006)

The result shows that the deviation of PMV value between CFD and measurement is about 0-20\%. As a consequence, PMV measurement needs a higher air velocity to achieve comfort under activity of 1 met. The simulated PMV results for the master bedroom are higher than other rooms. Further, at 12 noon, the PMV (between +2.0 and +2.25 ) is higher than at other times of the day. Thus the condition can be described as warm and uncomfortable. Therefore, decreasing PMV value is recommended to the required level.

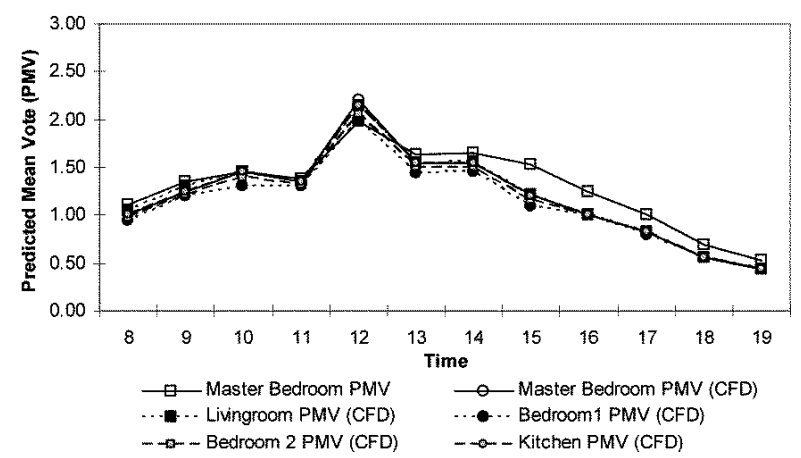

Fig.15. PMV calculation of a single storey terraced house (21 March 2006)

The most comprehensive study to establish the Malaysian comfort zone was done by Mohd Rajeh bin Mohd Saleh, 1989 (Nugroho, et al., 2006). The study used Auliciems' neutrality air temperature equation (combining the free running and actively controlled buildings) to define the comfort air temperature of Malaysians and proposed a bioclimatic chart showing the comfort zone for Malaysia based on the Olygay, 1958; Arens, 1984 and Szokolay, 1997 versions of the bioclimatic chart. With the width of the comfort 
zone taken to be $5^{\circ} \mathrm{C}$, thermal comfort air temperature extends approximately $2.5^{\circ} \mathrm{C}$ above and below the neutral air temperature. The upper limit of the comfort zone can be extended by providing natural ventilation or some form of air movement. With air movement of $1 \mathrm{~m} / \mathrm{s}$, the upper limit of Malaysia's comfort temperature can be extended by about $4^{\circ} \mathrm{C}$ to $33.2^{\circ} \mathrm{C}$. Fig. 16 . shows the proposed minimum air velocity for thermal comfort zone for Malaysia based on a bioclimatic version of the psychometrics chart (Nugroho, et al. 2006). According to Fig.16., for the temperatures between $26^{\circ} \mathrm{C}-33^{\circ} \mathrm{C}$ and relative humidity of $80 \%$ and $90 \%$, the average indoor air velocities at activity level $(1.1 \mathrm{~m})$ were found to be below the minimum required air velocity $(0.6 \mathrm{~m} / \mathrm{s}$ $-1 \mathrm{~m} / \mathrm{s}$ ) for thermal comfort condition.

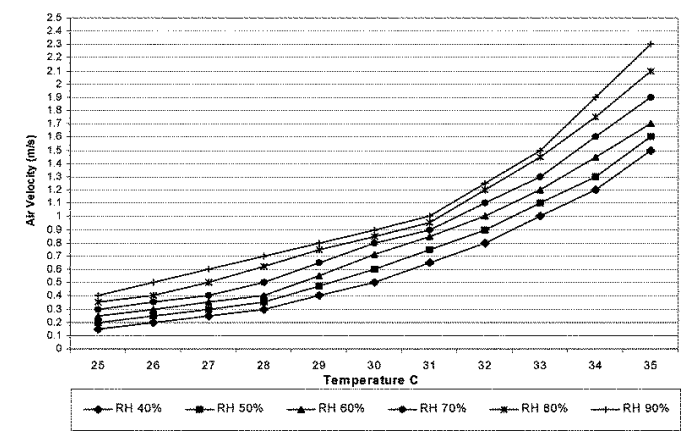

Fig.16. Minimum air velocity requirements for thermal comfort ventilation using bioclimatic chart

\subsection{Ventilation Modification to Improve Indoor Thermal Comfort}

The main interest of this study is to evaluate the effectiveness of ventilation modification to improve the indoor thermal comfort. Two parameters were established to evaluate and compare the ventilation modification of the master bedroom. The experiment hypothesized that ventilation modification can be achieved by stack induced ventilation using a solar chimney. However, in cases where the wind effect is not well captured, then the solar chimney may be a viable alternative. This strategy relies upon the heating of the building fabric by solar radiation resulting in a greater temperature difference (Awbi, 2004). In the past decade, solar chimneys have attracted much attention in various investigations Barrozi, 1992; Bouchair, 1994; Gan, 1997; Hirunlabh, 1999; Khedari, 2000; Alfonso, 2003; Waewsak, 2003; Ong, 2003; Drori, 2004; Satwiko, 2005 and Bansal, 2005 (Nugroho, et al., 2006). The solar chimney model is developed based on a previous study conducted by Nugroho (2006). The solar chimney geometry of $3 \mathrm{~m} \times 3.5 \mathrm{~m}$ $\mathrm{x} 1 \mathrm{~m}$ was installed on the roof of the single storey terraced house model. The reasons for this application may be a consequence of the following.

a. To reduce indoor air temperature

b. To increase indoor air velocity
3.6.1 Effects of Solar Chimney in Reducing Indoor Temperature

In this study, the potential of stack ventilation effects was assessed under similar conditions (terraced houses without solar chimney). With the effect of solar chimney, the release of heat gain from the room reduces the indoor air temperature below the outdoor air temperature. Fig.17. shows the daytime hourly air temperatures of the master bedroom, with and without a solar chimney. When the solar chimney was installed, the daytime mean air temperature was $28.5^{\circ} \mathrm{C}$. The average air temperature in the master bedroom ranges between $27.5^{\circ} \mathrm{C}$ and $31.1^{\circ} \mathrm{C}$ from $08.00 \mathrm{~h}-19.00 \mathrm{~h}$, which is about $0.5^{\circ} \mathrm{C}$ lower than a normal master bedroom terraced house without the solar chimney. The air temperature reduction by solar chimney is $1.5 \%$. Thus, the solar chimney cooling effect is relatively small.

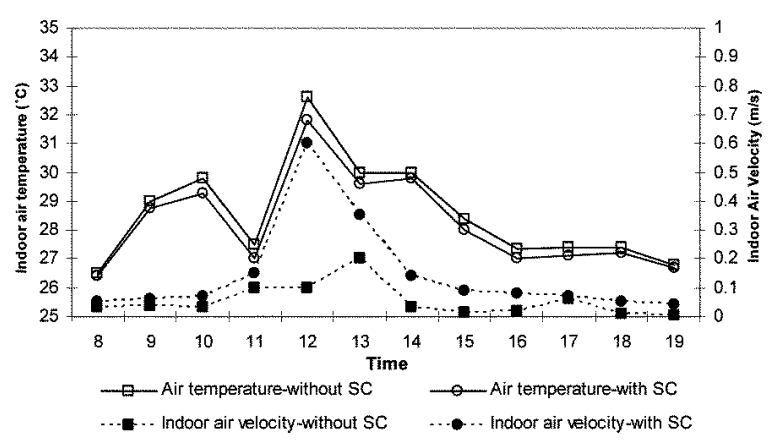

Fig.17. Air temperatures and air velocity of the master bedroom with and without solar chimney (21 March 2006)

\subsubsection{Effectiveness of Solar Chimney in Increasing Air} Velocity

The airflow velocities were calculated using CFD simulation for all performed hours. The average air velocity was observed at the same level of measurement points at $1.1 \mathrm{~m}$ above the floor. Further, for all cases, the computational simulations performed with CFD were in approximate agreement. Diversity in air velocity is observed in the case with solar chimney and the values ranging from $0.1 \mathrm{~m} / \mathrm{s}$ to $0.6 \mathrm{~m} / \mathrm{s}$ in the cross section of the simulated model (Fig.18.). It is found that in a terraced house using a vertical solar chimney, air ventilation is induced by the solar

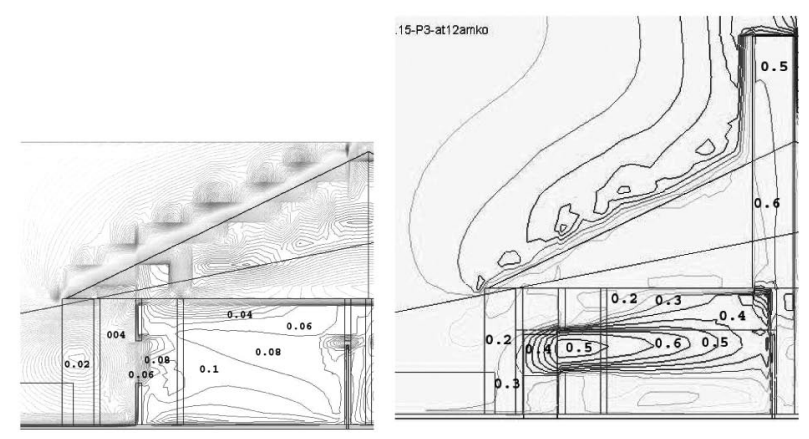

Fig.18. Air velocity pattern in vertical section (middle of the room) with and without solar chimney (21 March 2006) 
chimney. Results can be more significant by increasing maximum air velocity $(0.6 \mathrm{~m} / \mathrm{s})$ as well as cooling of air temperature. The highest and lowest air velocity is observed at $12.00 \mathrm{~h}$ and $19.00 \mathrm{~h}$ respectively (Fig.17.). The changing air velocities were dependant on the value of solar radiation at respective times.

Fig. 19. emphasizes the PMV resultant values obtained for the master bedroom with and without a solar chimney. The best PMV level $(+0.42)$ is indicated at $19.00 \mathrm{~h}$. The maximum improved thermal comfort condition was demonstrated with the PMV reduction by $37.8 \%$ at $13.00 \mathrm{~h}$. Thus the effective range of the air velocity in order to increase PMV level is $0.6 \mathrm{~m} / \mathrm{s}$ $-1.5 \mathrm{~m} / \mathrm{s}$. Further, this corresponds to the optimum geometry of the solar chimney that must be developed.

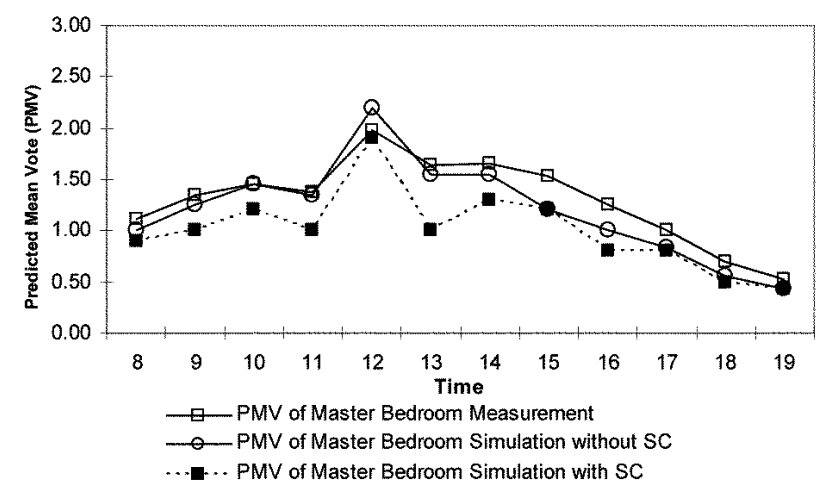

Fig.19. PMV of the master bedroom in a terraced house with and without solar chimney (21 March 2006)

\section{Conclusion}

The aim of the study is to validate the CFD Flovent program with the actual data on a selected date. The thermal conditions were also studied based on the climatic conditions on a selected date comparing the measured and simulated results. The study also emphasizes that installation of a solar chimney can affect the indoor thermal condition in a hot humid climate. The field measurement investigated the thermal environment and the thermal comfort in a selected room. The thermal environment results are inadequate to provide thermal comfort, especially in the master bedroom. This study proved that low air velocity of the single side ventilation (in the case of the master bedroom) decreases the indoor thermal comfort level. A comparison of the field measurement and CFD simulation showed that the simulation result is in good agreement with the field measurements. The estimated PMV thermal model by CFD simulation is lower than the PMV measurement. The study, based on the CFD thermal model, proved that a higher airspeed is needed to obtain the required thermal comfort. The last evaluation shows that natural ventilation performances can be improved when ventilation is modified, by installing a solar chimney in the existing terraced houses. Therefore, further experiments are required to determine the optimum solar chimney geometry to improve natural ventilation in buildings in hot and humid tropical climates.

\section{References}

1) Ansley, R.M., Vickery, B.J. (1999) "Architectural Aerodynamics". London: Applied Science Publishers Ltd.

2) ASHRAE Handbook Fundamentals (1989) "American Society of Heating and Air Conditioning Engineers" Inc. Atlanta.

3) De Wall, H.B. (1993) "New Recommendations for Building in Tropical Climate". Building and Environment 28 (3) pp.271-285.

4) Fanger, P.O. (1972) "Thermal Comfort". McGraw-Hill, New York, pp.244.

5) Griefahn, B. Künemund, U. Gehring, P. Mehnert. (2000) "Drafts in Cold Environments. The Significance of Air Temperature and Direction". Industrial Health 38, pp.30-40.

6) Humphreys, M.A, Nicol, J.F. (2001) "The Validity of ISO-PMV for Predicting Comfort Votes in Every-day Thermal Environments, Moving Thermal Comfort Standards into the 21 st Century". Windsor, UK, Loughborough University, pp.406-430.

7) Kubota, T., Supian Ahmad (2005) "Wind Environment Evaluation of Neighborhood Areas in Major Towns of Malaysia". Journal of Asian Architecture and Building Engineering, 5(1), pp.199-206.

8) Mayer, E. (1993) "Objective Criteria for Thermal Comfort". Building and Environment 28 (4) pp.399-403.

9) Nugroho, A.M and Hamdan, M. (2006) "Evaluation of Parametrics for the Development of Vertical Solar Chimney Ventilation in Hot and Humid Climate". The $2^{\text {nd }}$ International Network For Tropical Architecture Conference, at Christian Wacana University, Jogjakarta.

10) Prianto, E., Houpert, P. Depecker, J.-P. Peneau (2001) "Contribution of Numerical Simulation with SOLENE to Find Out the Traditional Architecture Type of Cayenne, Guyana, France". International Journal on Architecture Science, Hong Kong 1 (4) pp.156-180. 